\title{
Apokaliptiek en millennialisme: Die relevansie van die begrip "duisendjarige vredesryk" vir vandag ${ }^{1}$
}

\author{
Jonanda Groenewald \& Andries van Aarde \\ Departement Nuwe-Testamentiese Wetenskap \\ Universiteit van Pretoria
}

\begin{abstract}
Apocalypticism and millennialism: The relevance of the "thousand year reign" for today

With the turn of the century it once again became clear that apocalypticism and millennialism are important themes. At the dawn of a new millennium the expectancy arises that the end of the world is at hand. Apocalypticism deals with the end time and millennialism with the thousand-year reign. The purpose of this study is to look at the relevance of the "thousand year reign" for a postmodern person. The "thousand year reign", described in Revelation 20:1-10, is a concept that originated in the premodern time. Since there is a difference between how a premodern and a postmodern person understands time, it is important first to understand what this theme meant for the first readers of Revelation and then asking the question as to the relevance of this theme for today.
\end{abstract}

\section{INLEIDING}

\subsection{Wat is die vraag?}

Met die aanbreek van die jaar 2000 het dit weer eens duidelik geword dat apokaliptiek en millennialisme onderwerpe is wat besonder aktueel is. Die rede hiervoor is dat apokaliptiek handel oor die einde van die tyd en millennialisme oor die duisendjarige

\footnotetext{
1 Hierdie artikel is 'n verwerking van die MTh mini-skripsie van Jonanda Groenewald, voorberei onder leiding van Prof dr A G van Aarde, Fakulteit Teologie, Universiteit van Pretoria (2001).
} 
vredesryk, en dat 'n millenniumwending die verwagting skep dat die einde van die tyd op hande is. ${ }^{2}$

Die boek Openbaring is ' $n$ belangrike bron vir die bepaling van die eindtyd. In die besonder speel Openbaring 20:1-10 in hierdie verband 'n belangrike rol, omdat hier berig word oor die duisendjarige vredesryk. Deur die eeue heen het baie millennialistiese bewegings gekom en gegaan op grond van die verskillende interpretasies van die begrip "die duisendjarige vredesryk". Die doel van hierdie artikel is om aspekte van die agtergrond van apokaliptiek en millennialisme te bespreek, om sodoende die relevansie van die begrip "die duisend-jarige vredesryk" vir die postmoderne mens aan te dui.

\subsection{Wat is die probleem?}

Die begrip "die duisendjarige vredesryk" is afkomstig uit die premoderne konteks, omdat hierdie begrip in Openbaring voorkom en Openbaring ontstaan het in die eerste eeu. Die aanname kan daarom gemaak word dat postmoderniste 'n probleem met die hantering van 'n begrip soos "die duisendjarige vredesryk" sal hê. Hierdie mense handhaaf 'n wêreldbeeld waarin iets soos 'n duisendjarige vredesryk nie moontlik is nie. Vanweë die hedendaagse ontwikkelinge op die gebied van die teoretiese fisika, is die postmoderne mens bewus van die ingewikkeldheid van die begrip "tyd".

Teoretiese fisici wys uit dat die aarde al vyftien tot twintigduisend miljoen jaar gelede deur middel van 'n "oerknal"3 ontstaan het en dat die mens al vir ongeveer tweehonderd en vyftig duisend jaar op die aarde woon (kyk Hawking 1988:8-9, 116-141; 1993:77-90). ${ }^{4}$ Iets soos 'n duisendjarige vredesryk is volgens die oerknalteorie onmoontlik, maar ek dink dat Christene graag sal wil weet hoe hulle hierdie begrip uit Openbaring in hulle kennisraamwerk van vandag moet akkommodeer. 'n Verantwoordelike benade-

\footnotetext{
${ }^{2}$ Dat die draai van die eeu 'n groot invloed op die gemoedere van mense gehad het, is duidelik te sien in die films, boeke, koerant-, tydskrif- en internetartikels wat die afgelope paar jaar verskyn het (kyk o a Pike 1997:www.fas.org/2000/critical.htm; Boogart \& Boogart 1998-99:141; Cruz 1998-99:85; Hardboiled 3.3 Des 1999; Van Wyk 1999:5, 8).

${ }^{3}$ George Gamow is die pionier van die oerknalteorie. Hierdie teorie word vandag deur die meerderheid teoretiese fisici aanvaar as die manier waarop die heelal ontstaan het (kyk Gribbin 1996: epunix.biols.susx.ac.uk/Home/John_Gribbin/pgir.htm\#George_Gamow; Joubert 1997:236-240).

4 Kyk ook Nasa 1995:pao.gsfc.nasa.gov/gsfc/lithos/cobe/secret/secret.htm; Big Bang theory 1997: www.bowdoin.edu/dept/physics/astro.1997/astro4/bigbang.html; Joubert 1997:9-13, 18-22, 236-240; Du Toit 2000:105-114).
} 


\section{Apokaliptiek en millennialisme}

ring sal wees om nie van hulle 'n sacrificium intellectus ${ }^{5}$ te verwag nie. Dit is nie nodig om, soos in die modernistiese tyd, óf die wetenskap op te skort om in God te glo, óf die bestaan van God te ignoreer om wetenskaplik te wees nie. Küng (1988:1) verwys soos volg na hierdie uitdaging:

We are looking for a new direction, we are developing a program for theology...that can win for itself a new credibility and social relevance only through an intellectually responsible account of Christian faith which meets the demands both of the Gospel and of facing the third millennium. We need this account for the journey into a period of world history that...has been characterized by many analysts as no longer modern, but postmodern.

\subsection{Program van ondersoek}

Om aspekte van die agtergrond vir die verstaan van die verskynsels apokaliptiek en millennialisme te verduidelik, bespreek ek eerstens die tydsgees waarin ons ons vandag bevind en hoe ons siening van tyd verskil van dié van die premoderne mens (die tyd waarin die Bybel ontstaan het). Vervolgens gee ek 'n kort oorsig oor die betekenis en geskiedenis van millennialisme, waarna ek oor apokaliptiek as 'n vorm van eskatologie handel. Ten slotte poog ek om die relevansie van die begrip "die duisendjarige vredesryk" afdeling vyf vir vandag aan te dui.

\section{TYDSGEES}

\subsection{Verskuiwende paradigmas}

Die tydraamwerk waarbinne 'n mens lewe, beïnvloed alles wat jy doen, dink en sê (vgl Du Toit 2000:13-14). Oor die algemeen verdeel wetenskaplikes die geskiedenis van die mensdom in drie tydvakke, naamlik die premoderne, moderne en postmoderne paradigmas (vgl Kuhn 1966; Küng 1988; Van Aarde 1995a:20-24; Du Toit 2000:13-61).

Die premoderne wêreldbeeld word ook die voorwetenskaplike paradigma genoem. In hierdie tyd het die mense 'n mitiese siening van die wêreld gehad en het hulle die inhoud van die Bybel letterlik verstaan. Die moderne (of wetenskaplike) paradigma

5 'n Sacraficium intellectus is wanneer 'n mens jou rasionele of intellektuele vermoëns opskort (Du Toit 2000:141). 
het in 1514 'n aanvang begin neem toe Kopernikus ontdek het dat die aarde rond is en om die son draai. Hoe verder die natuurwetenskap ontwikkel het, hoe meer het die mense rasioneel begin dink en hoe minder het die inhoud van die Bybel vir hulle sin gemaak. Dit het selfs daartoe aanleiding gegee dat 'n groot klomp mense, omdat hulle nie die inhoud van die Bybel kon versoen met hulle wêreldbeeld nie, die Bybel nie meer as van toepassing geag het vir hulle lewens nie.

$\mathrm{Na}$ die twee wêreldoorloë het die optimisme in die mens en die tegnologiese vooruitgang begin verdwyn. Dit het aanleiding gegee tot die ontstaan van die postmoderne paradigma waarin ons ons tans bevind. ${ }^{6}$ Dit is ' $n$ tydperk waarin besef word dat daar nie so iets soos suiwer, objektiewe kennis bestaan nie. Alles is relatief en pluriform. Alle kennis is voorlopig en die waarheid is relasioneel. Myns insiens is hierdie 'n baie opwindende tyd. Waar daar in die moderne tyd slegs aandag gegee is aan die rasionele sy van 'n mens, het alle aspekte van menswees, insluitende die spirituele, nou weer belangrik begin word (kyk Du Toit 2000:56; vgl Küng 1988:197-200; Van Aarde 1990:297. $301)^{7}$

Die postmoderne raamwerk waarbinne ons lewe, maak dit in 'n sekere sin vir ons makliker om die boodskap van die Bybel te verstaan. Sonder om soos in die moderne tyd te moet kies tussen óf natuurwetenskaplike insigte óf die inhoud van die Bybel, kan ons vandag die Bybel se mitologiese wêreldbeeld kontekstueel lees en in ons eie wêreld invertaal. Op hierdie manier kan die boodskap van die Bybel steeds vir ons betekenis hê (kyk Du Toit 2000:90; vgl Van Aarde 1995b:43-45).

Hiervoor is dit egter van kardinale belang dat ons werklik sal probeer verstaan hoe die mense van die Bybelse tyd hulle wêreld verstaan het, sodat ons onsself nie skuldig maak aan anakronisme nie. As ons byvoorbeeld wil kyk na die relevansie van die uitdrukking "die duisendjarige vredesryk" vir vandag, sal ons eers moet kyk hoe die eerste-

\footnotetext{
6 Dit is belangrik om daarop te wys dat nie alle mense hulleself vandag in die postmoderne paradigma bevind nie. Terwyl daar nog baie mense is wat modernisties dink, is daar mense in Afrika, Asië, die Verre Ooste en Suid-Amerika wat steeds 'n premoderne wêreldbeeld handhaaf (Du Toit 2000:41-42). Aangesien ek in hierdie artikel op die postmoderne mens fokus, sal ek nie aan die twee ander groepe aandag gee nie.

${ }^{7}$ Dit is nie vir my moontlik om in hierdie kort bestck die ingewikkelde ontwikkeling en verskuiwing van paradigmas aan te dui nie. Hierdie kursoriese verduideliking dien bloot as agtergrond vir die verstaan van die verskynsel dat mense deur die loop van die eeue die Bybel op grond van hulle wêreldbeeld verskillend verstaan het. Vir 'n meer uitvoerige bespreking, kyk Kuhn (1966) en Küng (1988).
} 
eeuse mense tyd verstaan het, aangesien dit 'n temporele begrip binne die konteks van apokaliptiek en millennialisme is.

\subsection{Tyd in die eerste-eeuse Mediterreense wêreld}

Tyd vorm 'n integrale deel van ons lewens van elke dag - sonder dat ons noodwendig daarvan bewus is. Alles wat gebeur, word onderlê deur een of ander teorie van temporaliteit (kyk Hall 1976:14-18; McGrath 1988:7, 89; Malina 1996:180).

Die mense wat gedurende die gevorderde agrariese periode ${ }^{8}$ geleef het, se lewens was uit die aard van die saak ook deur tyd bepaal, maar hulle het tyd totaal en al anders verstaan as wat ons in die moderne en postmoderne periodes doen. As ons dus 'n temporele begrip soos "die duisendjarige vredesryk" wil verstaan, is dit nodig om eers te gaan kyk hoe die mense in wie se tyd hierdie begrip ontstaan het, gedink het oor tyd.

Oscar Cullmann (in Malina 1996:179) het 'n belangrike hermeneutiese uitspraak gemaak oor die rol wat tyd speel in die verstaan van die Nuwe Testament: "The frame within which the writers of the New Testament worked ought to be the same limits which New Testament scholars accept for their work." Met die uitdrukking "same limits" word waarskynlik die hermeneutiese benadering bedoel wat sedert Friedrich Schleiermacher as die "hermeneutiese sirkel" bekend staan (kyk Thiselton 1992:221-228). Alhoewel Cullmann 'n baie belangrike kwessie aanraak, het hy en sy tydgenote volgens Malina (1996:179) nie die tydsraamwerk van die Nuwe-Testamentiese skrywers toereikend verstaan nie. Vandag help sosiaal-wetenskaplike en kruis-kulturele antropologiese studies ons om te onderskei tussen moderne Westerse en antieke Mediterreense konsepte (kyk Malina 1981, 1996; Van Aarde 1994).

Die wêreldbeeld van die eerste-eeuse Mediterreense mens se oriëntasie was, wat tyd betref, gerig op die hede, terwyl mense in die moderne Westerse wêreld se orientasie gerig is op die toekoms. In ons moderne konteks word tyd meganies gekondisioneer deur middel van die horlosie. Oor die algemeen gesien leef mense vandag daarvoor om een of ander doel in die toekoms te bereik (kyk Malina 1996:181; vgl Van Aarde 1998:17-19). Die eerste-eeuse sosiale wêreld se fokus was op wat konkreet ervaar is. Mense van dié

\footnotetext{
8 Israeliete in Palestina het gedurende die eerste eeu in 'n pre-industriële, gevorderde agrariese samelewing geleef. In hierdie tyd het hulle begin om meer gevorderde boerderymetodes, soos die ploeg, aan te wend (kyk Van Aarde 1994:96-99; vgl Malina 1981:71-75).
} 
tyd het nie manupileerbare numeriese waardes geken nie; ook nie die gebruik van nul in wiskunde nie, hulle het nie 'n abstrakte en onpersoonlike kronologie en numeriese kalenders gehad nie en ook nie die abstrakte tydskategorieë van verlede, hede en toekoms nie. Die rede hiervoor is dat hulle sosiale sisteem, wat 'n landboukultuur was, nie hierdie dinge nodig gehad het nie (kyk Malina 1996:187-188).

Malina (1996:188) dui 'n paar basiese verskille aan tussen die hedendaagse en eerste-eeuse Mediterreense tydsverstaan. In teenstelling met hedendaagse abstrakte tyd, was daar in die eerste-eeuse Mediterreense wêreld ervaarde en verbeelde tyd. Antropoloë tref ook 'n onderskeid tussen hedendaagse liniêre verdeelbare tyd en tradisionele sikliese en prosedure tyd (kyk Van Aarde 1998:18-19).

Die mdustriële rewolusie het veroorsaak dat ons vandag in abstrakte of meganiese terme oor tyd dink. Ons praat numeries oor hoe lank iets duur en oor wat die belangrike dinge in die lewe is. Vir ons hou die toekoms moontlike uitkoms vir gebeure in die hede in (kyk Malina 1996:188). Vir die Mediterreense persoon wat slegs op die hede gekonsentreer het, was die realiteit slegs die ervaarde wêreld en ervaarde tyd. "Experienced time is the perception of duration solely within the perceived horizon of the world of actual experience" (Malina 1996:189). Hierdie "hede" sluit, buiten die beleefde hede, ook 'n horison van verlede en toekoms in wat gebind is aan die hede, omdat beide tot dieselfde betekeniskonteks behoort (kyk Bourdieụ, in Malina 1996:189). Hede dui op 'n eenduidige konteks van betekenis wat baie keer lank duur, afhangende van die proses wat daarby betrokke is.

Buiten die sfeer van die konkrete hede, was daar ook vir die mense van die eersteeeuse Mediterreense tyd 'n sfeer wat buite die horison van die ervaarde wêreld geval het, naamlik dit wat verbeel kon word. Verbeelde tyd het gehandel oor alles wat nie in die hede bestaan het nie. Die verbeelde wêreld is dié wêreld wat nie direk gekoppel kan word aan ervaring nie, maar wel in verhouding staan daarmee. Vir die Ou- en NuweTestamentiese gelowiges dui verbeelde tyd op die domein wat eksklusief aan God behoort, vir wie alle dinge moontlik is (kyk Malina 1996:192).

Die moderne siening van tyd is ook liniêr en verdeelbaar. Dit bestaan uit 'n verlede, hede en toekoms - 'n skedule waarvolgens een ding op 'n slag gedoen moet word en waarin progressie plaasvind (kyk Hall 1976:14-18). Ons kan ook na hierdie 
tydsperspektief verwys as "horlosie-tyd". Dit kan gedefinïeer word as 'n objektiewe, eksterne, nie-sosiale middel waarmee die duur en ontvouing van optrede gemeet kan word (Malina 1996:196-197). In teenstelling hiermee het die eerste-eeuse Mediterreense mense "sosiale tyd" gehad. Lauer (1981:21) beskryf sosiale tyd soos volg: “...by social time, I refer to the patterns and orientations that relate to social processes and to the conceptualization of the ordering of social life." Sosiale tyd is gegrond op sosiale verhoudings en transaksies en is beïnvloed deur die geskiedenis, gevoelens, geloof en waardes - dinge wat vir die eerste-eeuse mense belangriker was as geskeduleerde tyd (kyk Hall 1976:14; Lauer 1981:21-46; Malina 1996:197-198).

Sosiale tyd het twee dimensies gehad, naamlik sikliese en prosedure tyd. Sikliese tyd is gewortel in die beweging van die goddelik beheerde hemelliggame. Eerste-eeuse mense in die leefwêreld van die Bybel het geglo dat die hemelliggame veranderinge in die lewens van mense veroorsaak, aangesien dit deur God of die gode beheer is. Die herhaalde beweging van die hemelliggame het die eendersheid van die menslike lewe onderstreep, selfs te midde van verandering. As mense met 'n landboukultuur is hulle lewens bepaal deur die beweging van die maan, son en sterre. Sikliese tyd is dus 'n sinoniem vir menslike optrede wat gereeld en min of meer op dieselfde manier plaasvind, soos om te saai en te oes (kyk Malina 1996:199-201). Prosedure tyd is gewortel in die prosesse van biologiese organismes, byvoorbeeld die geboorte van 'n eerste seun, die huwelik en die bereiking van 'n hoë ouderdom. Hier is duur nie verstaan as 'n siklus nie, maar as ' $n$ proses. Sulke prosesse is belangrik vir die betekenis en gehalte van die lewe en moes korrek en volledig uitgevoer word. Dit is eenmalige of ongereelde gebeurtenisse. Die hele tydperk wat die prosedure geneem het om voltooi te word, is beskou as die hede. Dit was die voltrekking van die prosedure wat belangrik was, nie die tyd wat daarvoor gebruik is nie (kyk Malina 1996:202).

Die vraag is watter implikasies het hierdie eerste-eeuse Mediterreense verstaan van tyd vir ons interpretasie van die begrip die "duisendjarige vredesryk" en die konteks van millennialisme en apokaliptiek waarbinne hierdie begrip voorgekom het. $\mathrm{Al}$ drie hierdie terme het een ding in gemeen: dit verwys op verskillende maniere na ' $n$ proses waarvolgens dít wat nog in die toekoms lê, verander is in iets wat relevant was vir die hede van die vroeë Christelike generasies. Jesus is deur daardie hede-georïenteerde 
mense verstaan as die komende Messias met krag. Hierdie siening van hulle was geanker in hulle werklike, ervaarde tyd. Die messiaanse verwagting het egter as gevolg van die verloop van gebeure verby die horison van die teenswoordige ervaring geskuif na die "moontlike", die toekomstige verbeelde tyd (kyk Malina 1996:208; Van Aarde 2000:610).

Aangesien die Bybelskrywers hulleself totaal en al op die hede georienteer het en die toekoms volgens hulle slegs in die hande van God gelê het, sal die toekomsdimensie in bogenoemde terme in heroorweging geneem moet word. Dié toekomsdimensie (eskatologie) word volgens Malina (1996:210-211) oor die algemeen deur moderne eksegete anakronisties en etnosentrisities geïnterpreteer (kyk Schwarz 2000:2-6; vgl Borg 1986:95-97). Kennis van en insig in die verskil tussen die hedendaagse wêreldbeeld en verstaan van tyd en dié van die eerste-eeuse premoderne mens, is onontbeerlik vir die verstaan van die verskynsels millennialisme en apokaliptiek.

\section{MILLENNIALISME}

\subsection{Die betekenis van die begrip "millennialisme"}

Die term "millennium" is afgelei van die Latynse woorde mille (duisend) en annus (jaar). 'n Ander term wat ook gebruik word vir millennialisme, is "chiliasme" wat afgelei is van die Griekse woord XIXıós (duisend) (kyk Lohse 1985:1316-1318; Rist 1989b:381). ${ }^{9}$ 'n Millennium is dus 'n periode van 'n duisend jaar. Op grond van die idee van die duisendjarige vredesryk (kyk Op 20:1-10) word die millennium geassosieer met 'n finale, goue era in die geskiedenis van die mensdom (kyk Schwartz 1987:521; Bosch 1996:313; HAT 1998:701)..$^{10}$

Millennialisme hang ten nouste saam met die konsepte "eskatologie" en "apokaliptiek". Alhoewel nie een van hierdie begrippe dieselfde betekenis het nie, is dit nie moontlik om die een sonder die ander te verstaan nie (kyk Bosch 1996:313). Daar sal nou eers aandag gegee word aan millennialisme. Die begrip "millennium" het heel

\footnotetext{
${ }^{9}$ Kyk ook CSEC Library 1999:www.endtime.org/library/articles/mille.html.

${ }^{10}$ Kyk ook Penguin Hutchinson Reference Library 2001.
} 
waarskynlik ontstaan teen die agtergrond van die idee van oorlog tussen goddelike en sataniese magte, soos dit voorgekom het in die antieke Persiese godsdiens, Zoroastrisme (kyk Du Toit 2000:21-22)." Greto ${ }^{12}$ formuleer dit soos volg: "That faith pitted the universe starkly between a good god and a bad one, measuring their battles against each other as well as the ultimate victory of the good, in thousand-year intervals." Die grondterm in die millennialistiese denkstruktuur, "millennium", verwys dus na die oorlog tussen die magte van goed en kwaad, wat gevolg sal word deur ' $n$ duisendjarige regering van die martelare saam met Christus (terwyl die Satan gebind is), waarna die Satan finaal oorwin sal word, die laaste oordeel sal plaasvind en 'n nuwe hemel en nuwe aarde tot stand sal kom (kyk Op 20:1-10). Hierdie tussentydse aardse regering is letterlik die millennium (kyk Schwartz 1987:521-522). ${ }^{13}$

Millennialistiese denke gee soms aanleiding tot die ontstaan van millennialistiese bewegings. Schwartz (1987:527) skryf dit toe aan twee groepe faktore. In die eerste plek ontstaan millennialistiese bewegings as gevolg van gevoelens van relatiewe verlies (wat betref status, rykdom, sekuriteit of selfbeeld). Dit veroorsaak krisisse by mense. Sulke krisisse gee aanleiding tot persoonlike fantasieë oor ontsnapping uit die situasie, waaraan maklik vorm gegee word deur charismatiese individue. ${ }^{14}$ Tweedens, sê Schwartz (1987:527), ontstaan moderne millennialistiese bewegings uit die kontak tussen twee kulture waarvan een tegnologies die ander se meerdere is. Millennialisme versprei dan binne die gevestigde, ondergeskikte kultuur, waarvan die regeringsvorm krities bedreig word. Die nuwe aankomelinge, gewoonlik wit en geletterd, versteur die tradisionele familiale-, genesings- en landsregtelike sisteme. "At the millenarian core lies frustration; out of frustration squirms fantasy, and fantasy breeds violence" (Schwartz 1987:528).

\footnotetext{
"Kyk ook Millennialism: Competing Theories [s a]:www.religioustolerance.org/millenni.htm.

${ }^{12}$ Greto 1998:www.pufori.org/news/nws10129810.htm.

${ }^{13}$ Onder die wêreldgodsdienste kan ons twee verskillende millennialistiese denkstrukture onderskei: die een Zoroastriaans-Joods-Grieks-Christelik, die ander Hindoe-Boeddisties-Taoïsties-Confuciaans (kyk Schwartz 1987:524). Vir die doel van hierdie artikel sal ek egter net op eersgenoemde konsentreer.

14 "These prophets shape public expressions of protest at a time when more straightforward political action seems useless. In the necessary unsuccessful aftermath, millenarians master the cognitive dissonance between expectation and failure by perpetuating millenarian beliefs within a revised chronology and a new missionary plan. The underlying causes for feelings of deprivation will not have been resolved, so a millenarian tradition, halfway between social banditry and the politics of party, bums on" (Schwartz 1987:527).
} 


\subsection{Die oorsprong en geskiedenis van millennialisme}

Die Judees-Christelike millennialistiese tradisie kan in drie tydperke verdeel word: die periode $200 \mathrm{vC}$ tot $200 \mathrm{nC}$, vanaf die derde eeu tot en met die Reformasie en die periode vanaf die Reformasie tot die twintigste eeu (Van Aarde 2000:1-6).

\subsubsection{Die opkoms en ontwikkeling van apokalipties-millennialistiese sieninge (200 vC - $200 \mathrm{nC}$ )}

Apokaliptiek is ' $n$ geestesbeweging wat onder gelowiges ontstaan wanneer hulle meen dat hulleself niks meer aan die haglikheid van die wêreld kan verander nie. In krisistye soos hierdie maak hulle staat op God om vir hulle uitkoms te bied. Hulle glo dat God binnekort sal ingryp en die huidige wêreld tot 'n einde sal bring. Terselfdertyd sal God 'n nuwe orde vestig waarin hulle as gelowiges saam met God sal regeer. 'n Nuwe fase in die geskiedenis op aarde sal dus aanbreek (kyk Van Aarde 1994:78-80).

Vanaf die tyd dat die een groot wêreldmag na die ander oor die Israeliete geregeer het, het hulle gewonder wanneer God se beloftes waar sou word. Hierdie beloftes van seën en voorspoed het in skrille kontas gestaan met die hede wat vol droefheid en ongeluk was. Apokaliptiek het gedien as antwoord op die "waarom?" en "waarheen?" vrae (kyk Van Aarde 1994:79-80; Schwarz 2000:323).

Die Israeliete het geglo dat alles op 'n bepaalde tyd verander sal word. 'n Dag van oordeel, waarop die ontroue Israeliete en die heidennasies vernietig sal word, is as onvermydelik verwag. 'n Gedeelte van die Israeliete (die regverdiges) sal hierdie oordeel oorleef. Saam met die regverdiges wat alreeds gesterf het en nou opgewek sal word, sal hulle almal saam in Palestina lewe met Jahwe as hulle regeerder. Jahwe sal vanuit 'n herboude Jerusalem regeer, 'n Sion wat die geestelike hoofstad van die wêreld sal word en waarheen alle nasies sal stroom. Dit sal 'n regverdige wêreld wees, sonder enige swaarkry (kyk Cohn 1957:1-6). Op grond van onder andere Genesis 1:1-2:4a, 2 Henog 
33:1-2 en Psalm 90:4 $4^{15}$ is uitgewerk hoe lank die huidige wêreld nog sou bestaan. De Smidt (1993:82-83) is van mening dat die konsep oor die duisendjarige vredesryk heel waarskynlik hier begin het.

Die vroeë Christene het die apokaliptiese idees wat die Israeliete ontwikkel het, gebruik (kyk Van Aarde 1994:83-85). Teen die einde van die eerste eeu (ongeveer 70 $\mathrm{nC}$ ), het die Christene al meer geïsoleerd begin raak in hulle samelewing. Aan die een kant het die verhouding tussen die kerk en die sinagoge begin versleg (vgl Katz 1984:4376). Andersyds is die Christene ook deur die heidene verwerp, omdat hulle nie wou deelneem aan die Grieks-Romeinse kultiese aktiwiteite nie (kyk Koester 1992:3-15; Van Aarde 2000:10). Die Christene het hulleself as gemarginaliseerd beleef, wat aanleiding gegee het tot apokaliptiese denke (vgl Cohn 1957:7; Rist 1989b:381).

Die heel eerste na-Bybelse verwysing na die "millennium" as idee in Christelike literatuur, is heel waarskynlik 'n gelykenis wat vertel is deur die kerkvader Papias van Hierapolis (c 60-120) (in Iren, Haer 5.33.1-5; 35:1-12; 36 - kyk Hanson 1970:432; Daley 1997:238; Netherton [1999]:10). Soos wat die tyd verbygegaan het, het dit duidelik geword dat, ten spyte van die hoop wat in die harte van sommige mense geleef het, die millennium toe nie aangebreek het met Jesus se opstanding nie. Dit het egter nie tot pessimisme aanleiding gegee nie, aangesien daar steeds geglo is dat die millennium wél sal aanbreek - die vraag was net wanneer (Kyk Netherton [1999]:10; vgl Cohn 1957:10).

Dit het veroorsaak dat die gebeurtenis wat aanleiding moes gee tot die millennium, in heroorweging geneem is. As die millennium dan nie ingelei is met Jesus se opstanding nie, sou dit heel waarskynlik ingelei word deur sy tweede koms na die aarde.

\footnotetext{
15 In Genesis 1:1-2:4a is opgeteken hoe God die aarde in ses dae geskep en op die sewende dag gerus het. 2 Henog 33:1-2 is ook 'n weergawe van die skeppingsverhaal. Andersen (1983:33) vertaal dit so: “...God shows Enoch the epoch of this world, the existence of 7000 years, and the eighth thousand is the end, neither years nor months nor weeks nor days...On the $8^{\text {th }}$ day I likewise appointed, so that the $8^{\text {th }}$ day might be the $1^{\text {st }}$, the first-created of my week, and that it should revolve in the revolution of 7000 ... so that the 8 000 ...might be in the beginning of a time not reckoned and unending, neither years, nor months, nor weeks, nor days, nor hours...like the first day of the week, so also that the eighth day of the week might return continually..." In Psalm 90:4 staan die volgende: "Duisend jaar is vir U soos gister as dit verby is, soos een enkele wagbeurt in die nag." Op grond van die sewe dae wat dit geduur het om die aarde te skep en die feit dat duisend jaar vir God soos een dag is, is uitgewerk dat die aarde vir 7000 jaar sal bestaan. Die geskiedenis van die aarde sal vir 6000 jaar duur, terwyl die laaste duisend jaar 'n "rusperiode" sal wees, waarin God sy koninkryk sal stig. Daar word na hierdie verskynsel verwys as die "wêreldweek" (vgl Lohse 1974:468; Van Aarde 1994:81).
} 
Justinus die Martelaar (c 100-c 165) het so 'n premillennialistiese ${ }^{16}$ mening gehuldig en in sy Dialogus cum Tryphona Judaeo $(80-81,113,139)$ uitgespel (kyk Daley 1997:238; Netherton [1999]:10). Ander skrywers het in sy voetspore gevolg, byvoorbeeld Irenaeus van Lyons (c 130-c 200) (Haer 5.32 - kyk Netherton [1999]:11; Schwarz 2000:323-324). Vir Justinus en Irenaeus was die millennium dus 'n gebeurtenis wat eendag in die toekoms sou plaasvind. In die laat 100 s het baie Christene egter tekens begin sien dat die millennium imminent was, soos byvoorbeeld die Montaniste. In ongeveer 172 het Montanus verkondig dat die nuwe Jerusalem binnekort naby Frigië in wes-sentrale KleinAsië opgerig sou word (kyk Daley 1997:239; Netherton [1999]:11-12; Van Aarde $2000: 1-2) .^{17}$

\subsubsection{Vanaf die derde eeu tot en met die Reformasie (allegoriese millennialisme)}

In die vroeë 200 s het Hippolutus van Rome probeer om die imminente millennialistiese verwagtings te kalmeer. Hy het voorspel dat Christus die millennium eers in 496 sal laat aanbreek. Hy het hierdie datum uitgewerk op grond van sy bestudering van die boek Daniël (Hipp, Comm Dan - kyk Dunbar 1983:313-327). Hy het eers uitgewerk dat Christus 5500 jaar nadat die wêreld geskape is, gebore is. Daarna het hy uitgewerk dat die millennium 6000 jaar na die skepping van die wêreld sal aanbreek. Na hierdie duisendjarige regering, met ander woorde na 7000 jaar, sou die wêreld dan eindig. Hy was dus oortuig dat Christus 500 jaar na sy geboorte sou terugkeer na die aarde (Netherton [1999]:12; Van Aarde 2000:2-3).

In die Oosterse Kerk was dit die kerkvader Origenes (c 185-c 254), die hoof van die Aleksandrynse Skool en seker die invloedrykste van al die teoloë van die antieke kerk, wat met sy allegoriese interpretasie van die Bybel millennialisme 'n doodsteek

16 Premillennialiste glo dat die tweede koms van Christus voor die millennium gaan plaasvind. Premillennialisme word gesien as die pessimistiese sy van millennialisme. Aanhangers van hierdie denkrigting is oortuig daarvan dat groot evangelisasiepogings en die totstandbring van geregtigheid in die gemeenskap nie sal uitwerk nie. Hulle glo dat die Antichris beheer oor die hele wêreld het en almal sal verlei om God te verwerp. Die wêreld kan slegs hiervan gered word deur God se radikale ingryping. Verskillende denkrigtings word onderskei: historiese premillennialisme (kyk Cruz 1989-99:92-93; De Smidt 1993:88) en dispensionele premillennialisme (kyk Cruz 1989-99:93; Hesselink 1998-99:99; Schwarz 2000:332-337).

\footnotetext{
${ }^{17} \mathrm{Vgl}$ ook Enclycopaedia Britannica $1994-2000:$ members. eb.com/bol/topic?eu=54022\&sctn=1\&pm=1
} 
gegee het (kyk Or, Princ 2.11.2). ${ }^{18}$ Vir hom was die dade wat deur gelowiges verrig is, baie belangriker as die kronologie van die ontvouende millennium (kyk Netherton [1999]:12; vgl Daley 1997:239). Op hierdie manier kon Origenes die feit dat die heidene geglo het dat hulle oorgelewer is aan die noodlot, kontrasteer met die Christene se geloof dat 'n persoon se keuses belangrik is (vgl Cohn 1957:13; Rist 1989b:382; Van Aarde 2000:3).

Toe die Romeinse Ryk se vervolging teen die kerk in $303 \mathrm{nC}$ 'n hoogtepunt bereik het, is daar gespekuleer dat die einde van die wêreld besig was om aan te breek. Keiser Diokletianus is gesien as die eerste dier van Openbaring 13 en keiser Galerius as die tweede (kyk Netherton [1999]:12). Toe Konstantyn die stryd om keiser te word in $312 \mathrm{nC}$ gewen het, het hy die vervolging tot 'n einde gebring. Christene was verheug en Eusebius van Caesarea (c 260-340) het na Konstantyn verwys as.die "leier van die leër van God" wat uiteindelik opgedaag het (Eus, $H E$ 3.39.13; 7.24.1 - kyk Van Aarde 2000:3).

Op grond van hierdie gebeure was dit maklik om af te lei dat die millennium uiteindelik aangebreek het, en dat Christus se tweede koms sal plaasvind na die millennium. Hierdie tipe siening word postmillennialisme ${ }^{19}$ genoem. Toe Konstantyn in 313 $\mathrm{nC}$ die Christelike godsdiens as staatsgodsdiens verklaar het, het die millennialistiese invloed op die kerk grootliks verdwyn. Behalwe vir 'n paar uitsonderings, het die kerk in elk geval nooit millennialisme as 'n leer bely nie. ${ }^{20}$

Vroeg in die vyfde eeu het Augustinus van Hippo, wat in $386 \mathrm{nC}$ tot bekering gekom het, in die Westerse Kerk 'n leer daargestel wat voldoen het aan die nuwe eise van die tyd. Daarvolgens moes die boek Openbaring as 'n geestelike allegorie verstaan word

\footnotetext{
${ }^{18}$ Origenes het dus nie soos van sy voorgangers Daniël en Openbaring letterlik geïnterpreteer nie (kyk Netherton [1999]:12).

${ }^{19}$ Postmillennialisme word gesien as die optimistiese sy van millennialisme. Dit voorspel 'n toeneming van vreugde, vrede en geregtigheid op aarde tot aan die einde van die geskiedenis, deur middel van die prediking van die evangelie (wat moontlik gemaak word deur die werking van die Heilige Gees). Wanneer die grootste deel van die wêreld bekeer is tot die Christendom en daar amper niks meer sonde gedoen word nie, sal Christus terugkeer na die aarde toe. Postmillenniahisme motiveer dus die kerk om aktief betrokke te wees in die gemeenskap, sodat hierdie einde kan aanbreek (Cruz 1998-99:93; Schwarz 2000:332).

20 "The Catholic Church was now a powerful and prosperous institution, functioning according to a wellestablished routine; and the men responsible for governing it had no wish to see Christians clinging to outdated and inappropriate dreams of a new earthly Paradise" (Cohn 1957:14).
} 
en het die millennium al begin met die geboorte van die Christendom en is dit ten volle gerealiseer in die kerk. Hy het die regering van 'n duisend jaar verstaan as die "era van die kerk", wat opgevolg sou word deur die tweede koms van Christus. Hierdie siening, wat amillennialisme ${ }^{21}$ genoem word, het spoedig die nuwe ortodokse leer geword (vgl Cohn 1957:14; Rist 1989b:382; Wright [1999]:13-15). Augustinus het hierdie siening uitgespel in sy werk De Civitate Dei, boek 22 (kyk Dyson 1998; vgl Brown 1967:299312). Amillennialisme het die siening van byna al die Christene in die Weste gebly vir bykans ' $n$ millennium en ' $n$ half, insluitende die Reformatore in die 1600s (kyk Van Aarde 2000:4). Dit het egter nie beteken dat daar geen millennialistiese drome gedurende die Middeleeue gekoester is nie.

Aangesien die vasstelling van die Christelike kalender (met die uitdrukking anno Domini $^{22}$ nog relatief nuut was in $1000 \mathrm{nC}$, twyfel historici of die jaar 1000 sterk apokaliptiese betekenis vir Middeleeuse mense gehad het. Die enigste bewyse van millenniumkoors in hierdie tyd is 'n Burgundese monnik, Raoul Glaber, wat 'n paar jaar na die aanbreek van die jaar 1000 gepraat het van tekens en wonders wat rondom die jaar 1000 plaasgevind het, sowel as rondom die jaar 1033, 'n duisend jaar na Christus se dood en opstanding. Die draai van die eerste millennium het egter nie stil-stil verbygegaan nie, aangesien die laat-Middeleeuse mense tog belangestel het in spekulasies oor die eindtyd (kyk Daniel [1999]:16).

In $950 \mathrm{nC}$ het 'n monnik, genaamd Adso, die mees volledige verhandeling oor die Antichris, Chanson de Roland, tot op hede geskryf. Volgens hom sou die Antichris vanuit die Judese stam Dan kom. Voordat dit egter gebeur, moet daar eers 'n Frankiese koning regeer. Hierdie koning sal al die vyande van die Christendom oorwin en oor 'n vredevolle, Christelike wêreld regeer. Daarna sal hy na Golgota gaan om afstand te doen van sy kroon, wat die teken sal wees dat die Antichris aan die kom is (Daniel [1999]:16).

\footnotetext{
21 Amillennialiste sien die taal van Openbaring as simbolies. Dit raak veral die getalle 3, 5, 7, 10 en 12 asook sekere meervoude daarvan. Dit geld ook vir die getal 1000 ('n meervoud van 10). Amillennialiste verwag dus geen aardse lokus vir die millennialistiese regering van Christus en die gelowiges nie. Hulle regeer die kerk vanaf trone in die hemel en die sending kan groot hoogtes bereik ondat die Satan vasgebind is in hierdie era. In hierdie sin is die koninkryk van Christus baie realisties, dit gaan Christus se tweede koms vooraf en het 'n groot effek op die gebeure in die wêreld - ekklesiasties sowel as polities (kyk Cruz 1998-99:93).

22 Anno Domini beteken "in die jaar van ons Here". Dit dui die geboorte van Christus aan, waarvolgens die jaarkalender vasgestel is.
} 
Op daardie stadium was daar grootskaalse spanning tussen die nasionale en kerkleiers. Beide groepe het Adso se idee van 'n "Laaste Wêreldkeiser" gebruik om hulle optrede te regverdig. Dit, tesame met die feit dat die kerk korrup was en die kerkleiers nie in staat was om hervorming te laat plaasvind nie, het apokaliptiese idees aangevuur (kyk Daniel [1999]:16).

Die spanning tussen die keisers en pouse het 'n hoogtepunt bereik in die 1240s, toe pous Innocentius IV 'n "totale oorlog" ('n oorlog met swaard en met woorde) verklaar het teen keiser Frederick II. Frederick se volgelinge het hom as die messias en redder van die wêreld vereer. Hierteenoor het pous Innocentius en sy volgelinge Frederick as die Antichris gebrandmerk. Hierdie konflik het duidelik na vore gekom in apokaliptiese tekste tot in die 1300s (kyk Daniel [1999]:17; Van Aarde 2000:3-5). Ten spyte van die feit dat millennialisme nie 'n offisiële leer was nie, het die apokaliptiese tradisie dus bly voortbestaan in die populêre geloof (kyk Cohn 1957:14).

Die "swart dood", soos wat die builepes bekendgestaan het wat tussen 1347 en 1350 omtrent veertig persent van die Europese bevolking uitgewis het, sowel as die "Groot Skeuring" in 1378 wat die kerk verdeel het tussen die pouse in Avignon en Rome, het aanleiding gegee daartoe dat eskatologiese gedagtes hoogty gevier het (kyk Daniel [1999]:18). In hierdie tyd is die een regeerder na die ander gesien as die messias. Ten spyte van die feit dat die konings van Frankryk en Engeland beheer oorgeneem, het oor die kerk, het hulle egter nie die kerk hervorm nie. Teleurstelling in hulle leierskap het gehelp om apokaliptiese gevoelens latent te hou (kyk Van Aarde 2000:5-6).

\subsubsection{Vanaf die Reformasie tot en met die twintigste eeu (progressiewe millen- nialisme)}

In die jaar 1530 het Protestantse gedagtes soos 'n tornado oor 'n Europa getrek wat baie min verander het in 'n duisend jaar. Die Protestantse Reformatore van die sestiende eeu (van die Lutheraanse, Calvinistiese en latere Anglikaanse tradisies) was nie millennialiste nie - hulle het bly vashou aan die allegoriese'millennialisme ("gerealiseerde eskatologie") van Augustinus (kyk Wise [1999]:23; Van Aarde 2000:6).

Die Reformasie het egter ' $n$ radikale vertakking gehad, naamlik die Anabaptiste. Hierdie beweging het heel waarskynlik ontstaan as gevolg van Melchior Hoffman se 
prediking, wat gehandel het oor 'n letterlike millennialistiese regering van Jesus Christus op aarde. In teenstelling hiermee het Lutherane, Calviniste en Anglikaanse Reformatore millennialisme as "onkundige" en "kwaadwillige" spekulasie bestempel. Konfessionele geskrifte soos die Nege-en-dertig Artikels, die Augsburgse Konfessie en die Westminster Konfessie het enige siening van 'n letterlike, duisendjarige regering van Christus vermy (kyk Wise [1999]:23; Schwarz 2000:328; Van Aarde 2000:6). ${ }^{23}$

Alhoewel Augustinus se wêreldbeeld in die periode van die Reformasie gehandhaaf is, het dit nie meer stand gehou in die intellektuele rewolusie van die sewentiende en agtiende eeu nie. Vir die eerste keer kon Protestantse en Rooms-Katolieke kerkleiers dit regkry om millennialistiese gedagtes werklik te onderdruk (kyk Daniel [1999]:18). Gedurendẹ die negentiende eeu het industrialisasie egter 'n nuwe golf van millennialistiese sektes tot gevolg gehad. Hierdie millennialiste het in die algemeen bygedra tot die opkoms van die Bybels-georiënteerde en konserwatiewe beweging, bekend as fundamentalisme (De Smidt 1993:85-86). Millennialisme funksioneer vandag hoofsaaklik binne so ' $n$ fundamentalistiese konteks. Dit is egter wel duidelik dat die oorsprong van millennialisme in die konteks van die eerste-eeuse apokaliptiek te vind is. Spesifiek gaan dit terug na die uitdrukking "duisendjarige vredesryk" in die boek Openbaring. Om die vraag na die relevansie van hierdie uitdrukking vir vandag te beantwoord, vra dus opheldering van die verband tussen apokaliptiek en eskatologie. Ek is van mening dat apokaliptiek gesien moet word as 'n vorm van eskatologie.

\section{APOKALIPTIEK AS VORM VAN ESKATOLOGIE}

\subsection{Die betekenis van die begrip "eskatologie"}

Om apokaliptiek as 'n vorm van eskatologie te verstaan, is dit belangrik om duidelikheid te kry oor wat eskatologie beteken. Die woord "eskatologie" bestaan uit twee Griekse

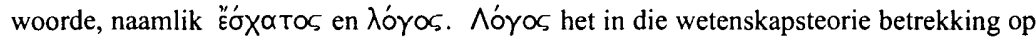

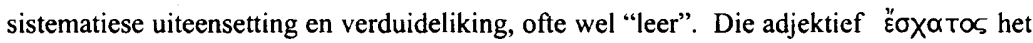
twee moontlike betekenisse in die Nuwe Testament, naamlik "om laaste te wees" of om die "minste belangrik" te wees (kyk Crossan 1998:258; Van Aarde 2000:7; vgl HAT 1988:209).

${ }^{23} \mathrm{Vgl} \mathrm{ook}$ Enclycopaedia Britannica 1994-2000:members.eb.com/bol/topic?eu=54022\&sctn=1\&pm=1. 
Ten spyte van die feit dat die begrip "eskatologie" nie 'n eerste-eeuse begrip is nie, het teoloë met die verloop van tyd 'n omvattende denkstruktuur ontwikkel rondom die betekenis van "om laaste te wees". Teologiese konsepte is anakronisties van toepassing gemaak op die Bybel, asof die Bybel hierdie konstrukte bevat en die woord "eskatologie" nie in die negentiende eeu eers ontstaan het nie (kyk Malina 1996:210-211; Van Aarde 2000:7-8). Eerste-eeuse Mediterreense mense se verstaan van tyd (soos reeds bespreek), kan nie buite rekening gelaat word as ons wil uitklaar hoe hulle "die laaste dinge", soos die "duisendjarige vredesryk", verstaan het nie.

"Eskatologie" verwys dus na 'n teologiese refleksie oor die einde van die "hemel" en die "aarde" as die skepping van God. Hierdie refleksie sluit ons geloof oor die tyd en omstandighede van die vervanging van die immanente wêreld deur die transendente wêreld van God in. In 'n sekere sin is die wêreld van God 'n "perfekte wêreld" wat staan teenoor die menslike kortstondige en korrupte wêreld (kyk Van Aarde 2000:9).

Omdat die betekenis van die uitdrukking "einde van die wêreld" nie eenduidig is nie, kan ons konkludeer dat daar 'n verskeidenheid eskatologieë is. ${ }^{24}$ Apokaliptiek kan gesien word as een van die eskatologieë wat in die simboliese universum van die eersteeeuse Mediterreense wêreld aangetref word (kyk Crossan 1998:259). ${ }^{25}$ Ander vorme van eskatologie is asketisme ${ }^{26}$, etiese of sosiale eskatologie ${ }^{27}$ en gebed (as vorm van kontem-

24 Eskatologie het volgens Crossan (1998:259-260) drie komponente. Dit dui in die eerste plek op 'n visioen of program wat radikaal, teenkultureel, utopies of wêreldontkennend is. Dit veronderstel dat daar iets fundamenteel met die wêreld verkeerd is, wat slegs reggestel kan word met iets van 'n radikaal teenoorgestelde aard. In die tweede plek word die mandaat van die visioen of program opgeneem as goddelik, transendentaal of bonatuurlik; dit is met ander woorde nie afkomstig uit menslike of natuurlike kragte of idees nie. In die derde plek, afhangende van waarom iemand die radikale en kosmiese "nee" aankondig en hoe iemand van plan is om daardie "nee" in die wêreld wat ontken word, uit te leef, is daar verskillende tipes eskatologiese uitdagings.

2s Apokaliptiese eskatologie ontken die wêreld deur aan te kondig dat God in die imminente toekoms die geregtigheid in 'n onregverdige wêreld sal herstel. Of dit aarde in die hemel of hemel op aarde inhou en of dit die einde van die ruimte-tyd heelal inhou of nie, is vaag en oop. Die feit dat God gaan ingryp en dat die bose iets van die verlede gaan wees, is egter onvermydelik (kyk Crossan 1998:283).

${ }^{26}$ Asketiese eskatologie ontken die wêreld deur middel van onttrekking van die normale menslike lewe. Hierdie onttrekking het betrekking op kos, seks, spraak, drag of beroep. Asketisme bring dus die wêreld tot 'n einde deur onder andere selibaatskap of vas (kyk Crossan 1998:265-271; 283-284; vgl Malina 1995:170172).

27 Etiese eskatologie eis van iemand 'n eties korrekte lewenstyl, in navolging van Jesus. Dit ontken die wêreld deur aktief te protesteer en nie-gewelddadig 'n sisteem wat as boos, onregverdig en gewelddadig beoordeel word, te weerstaan. God verwag dus van die méns om op te tree (anders as in apokaliptiese eskatologie waar dit God is wat optree) (kyk Crossan 1998:273-292; 284-285). 
the understanding and the behavior of the audience by means of divine authority" (Collins 1986:7).

Apokaliptiese eskatologie is 'n geestesbeweging wat onder gelowiges ontstaan wanneer hulle meen dat hulleself niks meer aan die haglike omstandighede in die wêreld kan doen nie. Dan gryp hulle na God vir uitkoms. Hulle glo dat God binnekort die bose wêreld tot 'n einde sal bring en 'n regverdige wêreld daar sal stel (vgl Rist 1989a:157; Van Aarde 1994:79-80).

\subsection{Apokaliptiese eskatologie}

Hedendaagse studies oor "apokaliptiese eskatologie" identifiseer 'n "sektariese mentaliteit" by die aanhangers daarvan. Met "sekte" word bedoel 'n minderheidsgroep wat gemarginaliseer is as gevolg van 'n krisissituasie, wat aanleiding gee tot 'n gevoel van vervreemding (vgl Hanson 1979:11-12; Van Aarde 1998:18-19; vgl Saldarini 1991:4448). 'n Sekte, soos die Qumran-gemeenskap van die eerste eeu, is 'n groep mense wat afgeskei het van die "ouerliggaam" en op die grense van die gemeenskap buite die hoofstroom lewe. Omdat hulle gemarginaliseerd is, blyk hulle slegs bewus te wees van twee kante van 'n saak deur dualisties te onderskei tussen reg en verkeerd, die goddelike en sataniese, die wêreld hier en nou en die wêreld hierbuite. Hulle wêreldbeeld word aan die een kant gekenmerk deur pessimisme en determinisme en aan die ander kant deur hoop: hulle beleef die huidige tydperk as onverdraagsaam en onderdrukkend, terwyl die transendente tydperk vreugdevol is. Sulke pessimisme en determinisme word gerelativiseer deur die oortuiging dat die gang van die geskiedenis verander kan word deur middel van gebede en die martelaarskap van die "regverdiges" (kyk Malina 1996:192193; Van Aarde 1998:18). Die apokaliptiese wêreldbeeld skep dus vir hierdie mense 'n nuwe en gesagvolle simboliese universum (kyk Sim 1996:54, 69; Van Aarde 2000:8).

Die krisis in die kulturele wêreld van Israel en die kerk wat aanleiding gegee het tot hierdie marginalisasie, het verband gehou met die spanning wat heidense magte op die kultus en die bestaan van die kerk geplaas het. Hierdie krisis is vergroot omdat die veronderstelde verhouding tussen daad en vergelding nie gerealiseer het nie. Die goddelose is nie gestraf nie en die regverdiges is nie sigbaar die oorwinnaars nie. "Ervaarde tyd" word as gevolg van hierdie verleentheid geprojekteer op 'n "verbeelde 
plasie). 'n Apokaliptiese perspektief oor die einde van die wêreld bestaan uit 'n kosmiese omwenteling en katastrofe, wat uitgedruk word deur simboliese taal en wat handel oor onder andere aardbewings, vallende sterre, duisternis, leë grafte en heilige oorloë (kyk Van Aarde 2000:9).

\subsection{Die betekenis van die begrip "apokaliptiek"}

Die term "apokaliptiek" is afgelei van die Griekse woord á beteken. Hierdie term is afgelei van die eerste woord van die laaste boek van die Bybel, naamlik die Openbaring van Johannes (kyk Murphy 1994:147; Van Aarde 1994:79; Sim 1996:23; Van Henten \& Mellink 1998:12-13).

Dit. is baie moeilik om so 'n omvangryke begrip soos apokaliptiek te definieër. Sim $(1996: 23,26)$ is van mening dat ons op die terrein van die apokaliptiek met 'n terminologiese probleem te doen het. Hy sê dat daar van hierdie een woord gebruik gemaak word om twee verskillende idees uit te druk. Aan die een kant dui dit op 'n spesifieke genre van Joodse en Christelike tekste wat fokus op die openbaring van hemelse geheime. Aan die ander kant beskryf dit 'n spesifieke eskatologiese wêreldbeeld. Daar is egter nie noodwendig 'n verband tussen die genre "apokalips" en die religieuse perspektief "apokaliptiese eskatologie" en die daarmee gepaardgaande sosiale beweging nie. Apokaliptiek is dus nie net 'n spesifieke soort literêre genre nie, maar ook 'n sosio-religieuse en kulturele verskynsel (vgl Barr 1998:154-159; Van Aarde 2000:6). ${ }^{28}$

Die Apocalypse Group of the Society of Biblical Literature Genres Project, het die volgende definisie vir die genre "apokalips" voorgestel: “"Apocalypse' is a genre of revelatory literature with a narrative framework, in which a revelation is mediated by an otherworldly being to a human recipient, disclosing a transcendent reality which is both temporal, insofar as it envisages eschatological salvation, and spatial insofar as it involves another, supernatural world" (Collins 1979:9). Later het hulle die volgende definisie oor die funksie van apokalipse bygevoeg: “...intended to interpret present, earthly circumstances in light of the supernatural world and of the future, and to influence both

${ }^{28}$ Die oudste apokaliptiese geskrifte waarvan ons kennis dra, dateer uit die derde en tweede eeu vC en is Joodse geskrifte, naamlik gedeeltes uit Daniël en 1 Henog/Etiopiese Henog (kyk Van Henten \& Mellink 1998:14-17). 
tyd" waarin God die beheer uitoefen - die koninkryk van God. Die uitdrukking "koninkryk van God" dui slegs in 'n baie besonderse sin die "einde van die wêreld" aan, naamlik dít wat in die toekoms met die skepping gaan gebeur (kyk Van Aarde 2000:9). ${ }^{29}$

\subsection{Apokaliptiek as ' $n$ alter staat van bewussyn}

Die mense in die leefwêreld van die Bybel het nie apokaliptiese denke (omdat dit gepaard gegaan het met figuurlike taal) as bonatuurlik (in teenstelling met die natuurlike wêreld) gesien nie. In die kulturêle konteks van die eerste-eeuse Mediterreense mens was die belangrikste onderskeid in hierdie verband dié tussen "skepper" en "skepping" (kyk Van Aarde 2000:6; vgl Pilch 1996:134-135). Saler (1977:43) verduidelik dit soos volg: "The domain of creation included not only human beings and other objects that we would describe as 'natural', but also entities that we should probably term 'spiritual': angels, for example, and demons. God...is clearly separate from all that he created." Die onderskeid tussen "natuurlik" en "bonatuurlik" is 'n Westerse kultureel bepaalde konsep en nie van nut in die verstaan van die eerste-eeuse Mediterreense leefwêreld nie. Hierdie onderskeid is eers vanaf die negende eeu gemaak (kyk Saler 1977:46, 51).

Hierdie "geestelike" belewenisse het aanleiding gegee tot 'n toestand wat 'n "alter staat van bewussyn" ${ }^{30}$ genoem kan word. Sonder hierdie insig uit die kader van die kulturele psigologie, sou rasioneel georienteerde mense in die Westerse wêreld van vandag nie anders kon as om Jesus se boodskap oor die koninkryk van God en die duisendjarige vredesryk anakronisties te verstaan nie (vgl Van Aarde 2000:6-7). Bourguignon (in Pilch 1993:235) verduidelik 'n alter staat van bewussyn soos volg: “...conditions in which sensations, perceptions, cognition and emotions are altered. They are characterized by changes in sensing, perceiving, thinking and feeling. They modify the relation of the individual to self, body, sense of identity, and the environment of time, space or other people." Antropoloë is van mening dat 'n alter staat van

\footnotetext{
29 Collins (1992:306) beskryf die drie eienskappe van mense by wie apokaliptiese eskatologie voorkom, naamlik marginaliteit, kognitiewe dissonansie en relatiewe verlies, soos volg: "Marginaliteit" is 'n sosiologiese term wat verwys na die sosiale status van 'n individu of ' $n$ groep as afwykend, periferies of vervreemd. "Kognitiewe dissonansie" verwys na 'n ingesteldheid wat onstaan wanneer daar 'n groot verskil tussen verwagtings en die realiteit is. "Relatiewe verlies" identifiseer die selfverstaan van mense wie se verwagtings of behoeftes nie bevredig word nie.

${ }^{30}$ Die doel van die bespreking van ' $n$ alter staat van bewussyn in hierdie gedeelte is slegs om die verskil tussen die antieke en modeme tydsbegrip te beklemtoon. Ek bespreek dus nie al die fasette daarvan nie.
} 
bewussyn ' $n$ universele menslike verskynsel is (Bourguignon 1973:9-11). Dit is slegs rasionalisties-georiënteerde, moderne Westerse mense wat probeer om dit te ontken (kyk Pilch 1993:233). 'n Alter staat van bewussyn word kultureel gevorm en kom meestal voor by mense wat slagoffers is van hulle omstandighede en nie hulle eie lewens kan verander nie (kyk Pilch 1993:236-237; vgl Bourguignon 1973:29-33). Insig in die dinamiek van 'n alter staat van bewussyn kan ons dus help om die apokaliptiese denkstruktuur beter te verstaan. Die visioene in Openbaring is byvoorbeeld die gevolg van 'n alter staat van bewussyn (kyk Pilch 1993:231-232).

Vanuit 'n sekere perspektief sluit apokaliptiek die siening in dat God se nuwe era spoedig sal aanbreek en dat dit ingelei sal word deur katastrofes met kosmiese dimensies. Wetenskaplikes is van oortuiging dat Jesus (en Johannes die Doper) verwag het dat God binnekort die hemelse koningkryk 'n aardse realiteit sou laat word. Daarom het die skrywers van die Nuwe Testament hierdie verwagting in verskillende grade aangekondig (kyk Van Aarde 2000:7). Hier is dit weer eens belangrik om die eerste-eeuse Mediteerreense verstaan van tyd (as ervaarde en verbeelde tyd) in ag te neem. Dit wat verbeel word, staan in verhouding met wat 'n persoon beleef. Die wêreld wat buite die ervaringswêreld val, vorm ' $n$ verlenging relatief met wat ervaar word in die immanente lewe. "Apokaliptiese eskatologie" verwys dus na belewenisse van "verbeelde tyd" wat in verhouding staan met ' $n$ bewussyn wat gemanifesteer is in belewenisse wat deur middel van visioene 'n transagtige kondisie (alter staat van bewussyn) veroorsaak (kyk Van Aarde 1998:18). Die mense wat in Jesus se tyd geleef het, het hierdie apokaliptiese verskynings as "natuurlik" beleef (Van Aarde 2000:8).

\section{DIE RELEVANSIE VAN DIE UITDRUKKING "DIE DUISEND- JARIGE VREDESRYK" VIR VANDAG}

\subsection{Wat het die uitdrukking “duisendjarige vredesryk" vir die eerste lesers van Openbaring beteken?}

Met die inagneming van alles wat tot dusver bespreek is, is dit nou moontlik om te probeer vasstel wat die eerste-eeuse Mediterreense mense verstaan het as hulle verwys het na die "duisendjarige vredesryk." 
Vanaf 63 vC was Palestina onder Romeinse beheer (Duling \& Perrin 1994:51). Kultureel gesproke het die mense van die eerste-eeuse Mediterreense wêreld 'n sterk religieuse bewussyn ten opsigte van hulle sosiale en simboliese wêrelde gehad. Soos reeds aangetoon, was gode, engele en demone 'n alledaagse deel van hulle verwysingsraamwerk. Enige krisis wat hulle in die werklikheid beleef het, is gesien as die invloed van demoniese kragte. 'n Voorbeeld hiervan is dảt die Romeine geglo het dat die stabiliteit van die staat verseker word deur die aanbidding van die gode in die heidense tempels, aangesien die keisers die Romeinse ryk gesien het as 'n replika van die "koninkryk van die gode" (kyk Koester 1992:10-13; Van Aarde 2000:10-11). Elke aktiwiteit in die eerste-eeuse Romeinse Klein-Asië het op een of ander manier erkenning aan die keiser (en sy goddelikheid) en aan die gode verleen (kyk Barr 1998:127, 164-169). Christene wat geweier het om deel te neem aan die verering van die gode, is dus vervolg omdat hulle as staatsondermynend gesien is (vgl Barr 1998:171, 178-179).

Hierdie situasie van vervolging en onderdrukking het daartoe aanleiding gegee dat die Christene hulleself as gemarginaliseerd beleef het. Dit het veroorsaak dat hulle hulle verlange geprojekteer het na 'n verbeelde wêreld, waar God in beheer is. Dit wat verbeel was, is uitgedruk in simboliese taal na analogie met wat in die alledaagse lewe beleef is (kyk Van Aarde 2000:10-11; vgl Duling \& Perrin 1994:456-457, 467-468). Hulle het geglo dat die "koninkryk van God", wat die teenoorgestelde van die "koninkryk van die gode of die keiser" was, spoedig sou aanbreek. Met die uitdrukking "koninkryk van God" het hulle nie 'n vergeesteliking van God se koninkryk bedoel nie, maar dat God op 'n ander manier koning is as die keiser, dat God anders regeer (kyk Van Aarde 2000:10). Vir die Christene was Jesus Kurios, die manifestasie van God - en nie die keiser nie. Hierdie boodskap is dan deur middel van simbole, wat gepas het by die apokaliptiese wêreldbeeld wat die vroeë Christene gehandhaaf het, oorgedra.

Die "utopie" van God se koninkryk is onder andere uitgedruk met getalle waarvan die simboliese waarde perfektheid of volledigheid was. Ook die keiser se ryk was met dieselfde waarde vanuit 'n heidense perspektief beskryf. Die getal tien is so 'n simbool vir volheid. Die Romeinse keiser is gesimboliseer deur 'n dier met tien horings, wat die volheid van sy regering uitgedruk het (Kyk Op 13:1). Volgens die ideologie van die keiserkultus is die Romeinse Ryk beskryf as die pax Romana, die "utopie" van perfekte 
regering en vrede vir die wêreld. Die idee van die duisendjarige vredesryk is dus 'n konsep wat op die teenoorgestelde van die idee van die pax Romana gedui het. Gesien vanuit Joods-Christelike perspektief, verteenwoordig die keiser hier die demoniese magte.

Ons lees in Openbaring 20:1-10 dat die Satan vir 'n duisend jaar vasgebind sal word, terwyl Christus en die gelowige martelare oor die wêreld sal regeer. Hierdie duisend jaar verwys na ' $n$ periode wat die volheid van die getal tien (van die keiser) by verre oortref. Terwyl tien 'n simbool vir volheid was, was drie die simbool wat gedui het op God. Drie maal tien $(10 \times 10 \times 10=1000)$ dui dus op goddelike volheid (kyk Botha 1989:380; Van Aarde 2000:11-12). Die duisendjarige vredesryk was dus vir die vroeë Christene God se tyd - die tyd waarin die bose magte gebind is sodat hulle God onverhinderd kan dien.

Die verhaal oor die duisendjarige vredesryk is dus nie 'n voorspelling oor wat in die toekoms gaan gebeur nie. Dit is 'n verhaal wat vertel word om aan die hede vorm en betekenis te gee. Dit wil duidelik maak dat die situasie waarin die Christene tans is, waarin dit voorkom asof hulle aan die verloorkant is (omdat baie van hulle 'n gewelddadige dood moes sterf ter wille van hulle geloof), eintlik 'n oorwinning is. Diegene wat in die "eerste opstanding" (Op 20:5) - die opstanding van Christus - deel, is die mense wat die dier weerstaan het. Hulle is die mense wat aan die kerk behoort (kyk Van Aarde 2000:14).

Dit wil dus voorkom asof die uitdrukking "die duisendjarige vredesryk" verwys na die periode van die kerk, waar demoniese kragte en vervolging steeds voorkom, maar wat wag vir die slag van Armageddon (Op 16:16), wat in werklikheid alreeds geveg en oorwin is toe die lam die oorwinning oor die dier behaal het by Golgota (Van Aarde 2000:12). Die "duisendjarige vredesryk" was dus nie vir die eerste lesers van Openbaring letterlik 'n periode van 'n duisend jaar wat nog in die toekoms gelê het nie.

\subsection{Wat is die relevansie van die uitdrukking "die duisendjarige vredesryk" vir vandag?}

Aangesien die mense in die moderne tyd grotendeels die inhoud van die Bybel letterlik verstaan het en nie die groot verskil tussen hulle wêreldbeeld en dié van die premoderne 
mense in ag geneem het nie, het die begrip "die duisendjarige vredesryk" twee verskillende reaksies tot gevolg gehad. Aan die een kant was daar mense wat as gevolg van die natuurwetenskaplike navorsing besef het dat iets soos 'n duisendjarige vredesryk nie moontlik is nie. Hulle het op grond hiervan besluit dat die inhoud van die Bybel nie waar is nie en dus nie van waarde vir hulle lewens is nie. Aan die ander kant het fundamentaliste hulle blind gehou vir die natuurwetenskap en geglo dat daar binnekort letterlik 'n duisendjarige vredesryk gaan aanbreek.

Met al die agtergrond wat ons nou het oor die premoderne mens se wêreldbeeld en verstaan van tyd, oor millennialisme en apokaliptiek en wat die gevolge van die verkeerde verstaan van die duisendjarige vredesryk in die geskiedenis was, kan ons nou probeer om vas te stel wat die betekenis van hierdie begrip vir die mens van vandag is. Dit is nie nodig om te kies tussen twee uiterstes, soos wat die moderne mens gedoen het nie. Met al die sosiaal-wetenskaplike navorsing wat daar al gedoen is oor die kultuurhistoriese agtergrond van die Nuwe Testament, het ons vandag 'n goeie idee hoe die eerste-eeuse Mediterreense mense tyd en getalle verstaan het. Om die betekenis van die uitdrukking "duisendjarige vredesryk" vir vandag vas te stel, is dit dus nodig om die eerste-eeuse mense se verstaan van dié begrip in ons wêreldbeeld in te tolk.

As dit vir die vroeë Christene beteken het dat God se koninkryk groter is as die pax Romana van die keiser en dat God dit deur Jesus Christus vir die Christene moontlik gemaak het om God ongehinderd te kan dien, kan dit tog nie vandag iets anders beteken nie! Hermeneuties sal dan gevra moet word watter sosiale instelling(s) vandag as van soortgelyke oppossionele waarde in terme van God se koninkryk gereken moet word. Verder sal gevra moet word watter waardes daar ter sprake is wanneer daar oor hierdie sosiale instelling(s) en oor God se koninkryk gepraat word.

'n Mens kan byvoorbeeld redeneer dat Augustinus in 'n sekere sin reg was toe hy gesê het die kerk die duisendjarige vredesryk simboliseer en dat hierdie domein kwalitatief gesproke totaal anders is as enige ander wêreldse krag. Ons lewe vandag as mense wat behoort aan die "stad van God", wat die waardes van Jesus Christus beliggaam en verkondig. Christus het ons Armageddon op Golgota geveg, sodat ons nou ongebonde en vry is om God te dien, terwyl die demoniese kragte gebind is (kyk Van Aarde 2000:14). 
Dit is dus nie nodig om 'n sacraficium intellectus te pleeg as ons die inhoud van die Bybel deel wil mak van ons lewens vandag nie. Dit is bloot nodig om moeite te doen om uit te vind wat 'n uitdrukking vir die eerste-eeuse mense beteken het en dit dán eers van toepassing te maak op ons eie lewens. Dit is nie moontlik om die Bybel letterlik en interpretasieloos toe te pas vandag nie, want dan sal ons juis 'n ander betekenis daaraan gee as wat die bedoeling was, omdat ons uitkyk op die wêreld so baie verskil van dié van die mense wat die Bybel geskryf het. Die uitdrukking "die duisendjarige vredesryk" wou troos aan onderdrukte Christene bring. Dit wou hulle bemoedig om vas te staan in die geloof, want al het die keiser gedink dat hy in beheer was van die wêreld, was dit eintlik God wat in beheer was - en is.

\section{Literatuurverwysings}

Andersen, F I 1983. 2 (Slavonic Apocalypse of) Enoch (Late First Century A D) with Appendix: 2 Enoch in Merilo Pravednoe, in Charlesworth, $\mathrm{J} \mathrm{H}$ (ed), The Old Testament Pseudipigrapha, Vol 1: Apocalyptic literature \& Testaments, 91-222. New York: Doubleday.

Barr, D L 1998. Tales of the end: A narrative commentary on the book of Revelation. Santa Rosa: Polebridge.

Big Bang theory 1997: www.bowdoin.edu/dept/physics/astro. 1997/astro4/bigbang html.

Boogart, P C \& Boogart T A 1998-99. The popular fiction of Tim LaHaye and Jerry B Jenkins. $\operatorname{RefR}(H)$ 52(2), 141-159.

Borg, M J 1986. A temperate case for a non-eschatological Jesus. Foundations \& Facets: Forum 2(3), 81-102.

Bosch, D J 1996. Transforming mission: Paradigm shifts in theology of mission.

Maryknoll: Orbis Books. (American Society of Missiology Series 16.)

Botha, F J 1989. s v “Openbaring”. Verklarende Bybel. Kaapstad: Lux Verbi.

Bourguignon, E (ed) 1973. Religion, altered states of consciousness, and social change. Columbus: Ohio State University Press.

Brown, P 1967. Augustine of Hippo: A biography. Berkeley: University of California Press.

Cohn, N 1957. The pursuit of the millennium. London: Stecker \& Warburg. 
Collins, A Y 1986. Introduction: Early Christian apocalypticism. Semeia 36, 1-12.

- 1992. Apocalypse and politics. Foundations \& Facets: Forum 8(3\&4), 297-312.

Collins, J J 1979. Introduction: Towards the morphology of a genre. Semeia 14, 1-20.

Crossan, J D 1998. The birth of Christianity: Discovering what happened in the years immediately after the execution of Jesus. San Francisco: HarperSanFrancisco.

Cruz, V A 1998-99. Jesus shall reign: A Biblical understanding of the Millennium. $\operatorname{RefR}(H)$ 52(2), 85-96.

CSEC Library 1999. s v "Millenarianism" www.endtime.org/library/articles/mille. html.

Daley, B E 1997. s v "chiliasm". Encyclopedia of Early Christianity, Vol 1. $2^{\text {nd }}$ ed.

Daniel, E R [1999]. Medieval apocalypticism: Looking for "the last emperor". Christian History 61, 16-18.

De Smidt, J C 1993. Chiliasm: An escape from the present into an extra-Biblical apocalyptic imagination. Scriptura 45, 79-95.

Duling, D C \& Perrin, N 1994. The New Testament: Proclamation and parenesis, myth and history. $3^{\text {rd }}$ ed. Fort Worth: Harcourt Brace.

Dunbar, D G 1983. The delay of the parousia in Hippolytus. VigChr 37, 313-327.

Du Toit, B 2000. God? Geloof in 'n postmoderne tyd. Bloemfontein: CLF Uitgewers.

Dysan, R W 1998. Augustine, City of God, ed \& tr by R W Dyson. Cambridge: Cambridge University Press.

Encyclopaedia Britannica 1994-2000. s v "millennium". members.eb.com/bol/topic? $\mathrm{eu}=54022 \& \operatorname{sctn}=1 \& \mathrm{pm}=1$.

Greto, V 1998. Book of Revelation, ancient miscalculation add mistique to millennial madness. www.pufori.org/news/nws $10129810 . \mathrm{htm}$.

Gribbon, J 1996. Cosmology for beginners. epunix.biols.susx.ac.uk/Home/John_ Gribbin/pgir.htm\#George_Gamow.

Hall, E T 1976. Beyond culture. Garden City, NY: Doubleday.

Hanson, P D 1979. The dawn of apocalyptic: The historical and sociological roots of Jewish apocalyptic eschatology. Rev ed. Philadelphia: Fortress.

Hanson, R P C 1970. Biblical exegesis in the early church, in Ackroyd, P R \& Evans, C $\mathrm{F}$ (eds), $C H B$, Vol 1, 412-153. Cambridge: Cambridge University Press. 
Hardboiled 3.3 Dec 1999. Asian Pacific America: End of the semester, end of the millennium, end of the world, pl.

HAT 1988. s v "eskatologie". 2de uitg.

Hawking, S 1988. A brief history of time: From the big bang to black holes. Great Britain: Bantam.

- 1993. Black holes and baby universes and other essays. Great Britain: Bantam.

Hesselink, I J 1998-99. The Millennium in the Reformed tradition. RefR(H) 52(2), 97 125.

Joubert, G 1997. Die groot gedagte: Abstrakte weefsel van die kosmos. Kaapstad: Tafelberg.

Katz, S T 1984. Issues in the separation of Judaism and Christianity after $70 \mathrm{C} \mathrm{E}$ : A reconsideration. $J B L 103,43-76$.

Koester, H 1992. Jesus the victim. JBL 111, 3-15.

Küng, H 1988. Theology for the third millennium: An ecumenical view, tr by $\mathrm{P}$ Heinegg. New York: Doubleday.

Kuhn, T S 1966. The structure of scientific revolutions. Chicago: University of Chicago Press. (International Encyclopedia of Unified Science II/2.)

Lauer, R H 1981. Temporal man: The meaning and uses of social time. New York: Praeger.

Lohse, E 1985. s v Chiliás. Theological Dictionary of the New Testament: Abridged in one volume, by $\mathrm{G} \mathrm{W}$ Bromiley.

Malina, B J 1981. The New Testament world: Insights from cultural anthropology. Louisville: John Knox.

- 1995. Pain, power and personhood: Ascetic behavior in the ancient Mediterranean, in Wimbush, V L \& Valantasis, R (eds), Ascetism,162-177. New York: Oxford University Press.

- 1996. The social world of Jesus and the Gospels. London: Routledge.

McGrath, J E (ed) 1988. The social psychology of time: New perspectives. Newbury Park: Sage Publications.

Millennialism: Competing Theories [s a]: www.religioustolerance.org/millenni.htm. 
Murphy, F J 1994. Apocalypses and apocalypticism: The state of the question. $C R: B S 2$, 147-179.

Nasa 1995. COBE: Revealing secrets of the Big Bang. pao.gsfc.nasa.gov/gsfc/lithos/ cobe/secret/secret.htm.

Netherton, D [1999]. Historic premillennialism: Taking the long view. Christian History $61,10-12$.

Penguin Hutchinson Reference Library 2001. s v "millennium". Disk A, CD produced by Future Publishing, Bath.

Pike, J 1997. FAS Millennia Monitor: Critical perspectives. www.fas.org/2000/ critical.htm.

Pilch, J J 1993. Visions in revelation and alternate consciousness: A perspective from cultural anthropology. Listening: Journal of religion and culture 28(3), 231-244.

- 1996. Altered states of consciousness: A "kitbashed" model. BTB 26(3), 133-138.

Rist, M 1989a. s v "apocalypticism". IDB, Vol 1.

- 1989b. s v "millennium". IDB, Vol 3.

Saldarini, A J 1991. The Gospel of Matthew and Jewish-Christian conflict, in Balch, D (ed), Social history of the Matthean community: Cross-disciplinary approaches. Minneapolis: Fortress.

Saler, B 1977. Supernatural as a western category. Ethos 5, 31-53.

Schwarz, H 2000. Eschatology. Grand Rapids: Eerdmans.

-1987. s v "millenarianism". The Encyclopedia of Religion, Vol 9.

Sim D C 1996. Apocalyptic eschatology in the gospel of Matthew. Cambridge: Cambridge University Press. (MSSNTS 88.)

Thiselton, A C 1992. New horizons in hermeneutics. Grand Rapids: Zondervan.

Van Aarde, A G 1990. Holisme as 'n postmodernistiese filosofie in teologiese lig. HTS 46(3), 293-311.

- 1994. Kultuurhistoriese agtergrond van die Nuwe Testament: Die eerste-eeuse Mediterreense sosiale konteks. Pretoria: Kital.

- 1995a. Kerk en teologie op pad na die derde millennium: 'n Paradigmatiese verskuiwing van middelmatige aard. HTS 51(1), 13-38. 


\section{Apokaliptiek en millennialisme}

Van Aarde, A G 1995b. Kerk en teologie op pad na die nuwe millennium: Gedagtes oor die kontekstualisering van die dialektiese teologie in 'n plurale samelewing. HTS 51(1), 39-64.

- 1998. Matthew 27:45-53 and the turning of the tide in Israels's history. $B T B 28(1)$, 16-26.

- 2000. Millennialism, eschatology, and apocalypticism. Ongepubliseerde toespraak, Graduation Ceremony, Hervormde Teologiese Opleiding, 15 November 2000.

Van Henten J W \& Mellink O (reds) 1998. Visioenen aangaande het einde: Apocaliptische geschriften en bewegingen door de eeuwen heen. Zoetermeer: Meinema.

Van Wyk, D J C 1999. Die einde van die wêreld: Die betekenis van apokaliptiek en die Boek Openbaring vir die kerk op die drumpel van dic een en twintigste eeu. Die Hervormer 15 Feb, bl 5, 8.

Wise, R L [1999]. Reformation apocalypticism: Münster's monster. Christian History 61, 23-25.

Wright, D [1999]. Amillennialism: Millennium today. Christian History 61, 13-15. 